\title{
Behavior of beef cattle in silvipastoral systems with eucalyptus
}

\section{Wander de Souza ${ }^{1}$, Orlando Rus Barbosa ${ }^{2}$, Jair de Araújo Marques ${ }^{3}$, Eliane Gasparino², Ulysses Cecato ${ }^{2}$, Leandro Martins Barbero ${ }^{4}$}

\author{
1 Instituto Paranaense de Assistência Técnica e Extensão Rural - Emater. \\ 2 Universidade Estadual de Maringá - UEM. \\ 3 Universidade Federal do Recôncavo da Bahia - UFRB. \\ 4 Universidade de São Paulo - Escola Superior de Agricultura "Luiz de Queiroz"
}

ABSTRACT - It was aimed to verify the effect of the presence of trees and their heights in silvipastoral system on the intake behavior of Nellore heifers in the summer. Ten heifers for the following systems were used: system without shade, silvipastoral system with 8-meter and 18-meter trees. The data were collected in three days during 12 hours, subdivided in morning (7:15 a.m. to 1. p.m.) and afternoon (1:15 p.m. to 7 p.m.). It was evaluated the times and frequency of grazing, rumination, idle and the percentage of time that the animals remained in the shade; black globe-humidity index, whose average and minimum values (86 and 82) were equal for 8-meter tree system and 18-meter tree system; however they were lower when compared to the without shade system (89 and 86). There was an interaction between the systems and the periods for all the analyzed variables, except for the rumination frequency. For system without shade, the grazing time did not differ between morning (202 min) and afternoon (187 min); however the grazing frequency was lower for the afternoon (3.17). For 8-meter trees systems and 18 meter trees system, the grazing time in the afternoon, respectively, with 195.50 and 219.00 min was higher than in the morning, respectively, with 128.00 and 158.50 minutes. The rumination time was higher in the morning for all systems. The grazing frequency for 8-meter trees was 3.58, for the without shade system it was 3.05 and for 18-meter tree system it was 2.22. A higher idle time and the idle frequency was found in system without shade $(97.50 \mathrm{~min}$ and 3.80 respectively) in the afternoon. For 8-meter tree system (98.50 min and 4.47 respectively) and 18-meter tree system (127.00 min and 4.27 respectively), they were higher in the morning The animals remained under shade for an average of 43.49\% (with trees with $8 \mathrm{~m}$ ) and $49.81 \%$ (with trees with $18 \mathrm{~m}$ ) of the time. It was concluded that the presence of trees modify the time and the frequency in grazing and idle; however, it does not influence the time and frequency in rumination.

Key Words: ambience, indle, index, rumination, shade, tree

\section{Comportamento de bovinos de corte em sistemas silvipastoris com eucalipto}

RESUMO - Objetivou-se verificar o efeito da presença de árvores e de sua altura em sistema silvipastoril sobre o comportamento ingestivo de novilhas aneloradas no verão. Utilizaram-se dez novilhas por sistema: sistema sem sombra e sistema silvipastoril com árvores de $8 \mathrm{~m}$ ou de $18 \mathrm{~m}$ de altura. Os dados foram coletados em três dias, durante 12 horas, subdividos no período da manhã (7h15 às 13 h) e da tarde (13h15 às 19 h). Avaliaram-se os tempos e as frequências de pastejo, ruminação, ócio e a porcentagem do tempo que os animais permaneceram à sombra; e o índice de temperatura do globo e umidade, cujos valores médios e mínimos (86 e 82) foram iguais para os sistemas com árvores de 8 e 18 m de altura e menores para sistema sem sombra (89 e 86). Houve interação entre os sistemas e os períodos para todas as variáveis, com exceção da frequência de ruminação. No sistema sem sombra, o tempo de pastejo não diferiu entre os períodos da manhã (202 min) e da tarde (187 min), no entanto a frequência de pastejo foi menor no período da tarde (3,17). Nos sistemas com árvores de $8 \mathrm{~m}$ e de $18 \mathrm{~m}$, o tempo em pastejo no período da tarde (195,50 e 219,00 minutos, respectivamente) foi maior que no período da manhã (128,00 e 158,50 minutos, respectivamente). O tempo de ruminação foi maior no período da manhã em todos os sistemas. A frequência de ruminação foi de 3,58 para o sistema com árvores de $8 \mathrm{~m}$; 3,05 para o sistema sem sombra; e de 2,22 para o sistema com árvores de $18 \mathrm{~m}$. Maior tempo e frequência de ócio foram encontrados no sistema sem sombra (97,50 min e 3,80, respectivamente) no período da tarde, enquanto, nos sistemas com árvores de $8 \mathrm{~m}$ (98,50 minutos e 4,47, respectivamente) e de $18 \mathrm{~m}$ (127,00 minutos e 4,27, respectivamente), foram maiores no período da manhã. Os animais permaneceram sob a sombra em média 43,49\% (sistema com árvores de $8 \mathrm{~m}$ ) e 49,81\% (sistema com árvores de $18 \mathrm{~m}$ ) do tempo. A presença de árvores altera o tempo e a frequência de pastejo e ócio entre os períodos da manhã de tarde, mas não influencia o tempo e a frequência de ruminação.

Palavras-chave: ambiência, árvores, índices, ócio, ruminação, sombra 


\section{Introduction}

Ethology studies the behavior and the vital manifestations of the animals in their natural environment or in environments modified by the man. The knowledge of the behavior of animals is essential for obtaining optimum conditions for breeding and feeding in order to get maximum production efficiency (Swenson, 1988).

Climatic factors, whose interaction affects both human and animal welfare, are moisture, temperature, air movement and solar radiation. In indoors and interiors of buildings, you can control these factors by keeping the microclimatic conditions within or very close to the limits of the "comfort zones". In outdoors, the control of the microclimate is possible by planting trees and shrubs making it possible to obtain minimum levels of comfort (Detzel, 1992).

The protection provided by the shade is a barrier to thermal radiation, and not to the heat, because it does not change the air temperature. Nevertheless, due to high levels of solar radiation in tropical areas, this protection is essential and there are many researches that suggest that the mere existence of shade of trees in pastures can favorably alter animal performance (Silva, 2000).

Paranhos da Costa (1987) observed that, although the air temperature and wind speed were important in determining the effectiveness of cooling mechanisms on clear days, the solar radiation was the most important climatic element to predict the use of shade. In another words, as the cooling mechanisms were not sufficient to prevent the increase in body temperature under conditions of intense solar radiation, the main responses were the search for shade and water intake.

The climatic variations influence the ingestive behavior of animals and it is shown that animals modify their activities in food intake and water consumption according to the climatic elements incidence on them. The use of shading favors environmental conditions (thermal comfort) for animals by changing their behavior (Marques, 2006).

The objective of this study was to evaluate the effect of the presence of trees and their height in silvipastoral systems on the ingestive behavior of Nellore heifers.

\section{Material and Methods}

The experiment was conducted in March 2007 in the northwestern Paraná, near the city of Paranavaí, which is characterized by the Cfa mesothermal humid subtropical climate, according to the classification of Köppen (Iapar, 1994).
It was evaluated the behavior of cattle beef in three systems: the first, without shade, made up by Panicum maximum cv Tanzania; the second, silvipastoral systems intercropped with Brachiaria brizantha cv Marandu, with two years of implementation and trees with an average height of 8 meters; the third, silvipastoral systems shaded by Panicum maximum cv Mombaça, with six years of deployment and trees with average height of 18 meters. For observation of behavior, it was delimited an area of 1.5 ha in each system. In all systems with trees (Eucalyptus), they were arranged in rank, following the ground level, with average density of 160 trees per hectare, $2.5 \mathrm{~m}$ between trees, 20 to $35 \mathrm{~m}$ spacing between ranks. In silvopastoral systems, the trees weren't pruned during their development.

Thirty Nellore heifers previously adapted to each environment were distributed within the three systems, with live weight of $260 \pm 20 \mathrm{~kg}$, individually identified, with non-toxic paint at the wither height.

The behavior of animals was observed by using the focal sampling route method and instant collection route (Martin \& Bateson, 1993).

Observations of behavior were performed for 12 hours a day for three days, every 15 minutes. Data was collected in three days for 12 hours, subdivided in morning (7:15 a.m. to 1 p.m.) and afternoon (1:15 p.m. to 7 p.m.). The observations were carried out by pairs mounted on horses, who were alternated every 6 hours, as described by Silva et al. (2006). It was observed animals grazing in the sun and shade, ruminating in the sun and shade, and idling in the sun and shade. The activities were noted in specific ethograms and, at the end of the performance evaluation, they were totalized in minutes per system, in each period per day, according to the methodology used by Hughes \& Reid (1951) and Marques et al. (2005).

Behavioral activities were considered mutually exclusive, e.g., at each record, each animal was classified in only one activity. The grazing time included the time spent in the selection of grazing sites, seizure and manipulation of the bolus. The rumination time included the time spent in regurgitation and bolus rechewing, and the time between swallowing and regurgitation. The idle time included the time that the animals showed no activity or grazing jaw movements (Thurow, 2009). The position of the shade represented the period when the animal was with $50 \%$ or more of the body under the shade of the rank. To check the shift between activities, it was calculated the frequencies in grazing, rumination and idle, considering frequency the sum of the times that each animal returned to the same activity. 
In the shading system (8 $\mathrm{m}$ and $18 \mathrm{~m}$ trees), it was recorded wind speeds, air temperature, air relative humidity, black globe temperature at the geometric center of the shade and between rank (fixed) and in the without shade system, it was recorded the same variables, but in a fixed location.

The environmental variables (wind speed, air temperature and relative humidity) were collected by using pocket weather station (THAL-300 ${ }^{\circledR}$ ). The black globe temperature was obtained with the use of a globe with black plastic ball with $15 \mathrm{~cm}$ diameter and alcohol column thermometer.

In order to assess the shade, the equipments were lined up at $1.60 \mathrm{~m}$ above the ground, simulating the height of the dorsum of the animal (Silva et al., 1995). In the horizontal position, they were placed approximately $0.5 \mathrm{~m}$ away from the trunk of the tree or from the geometric center of the projected shade. The equipments were moved in accordance to the inclination of the sun and consequently to the movement of the shade, with a previous study of this displacement.

The collection of climate data was performed simultaneously with the collection of behavioral data, every hour from 7 a.m. to 6 p.m.. For the evaluation of environments, the black globe-humidity index (BGHI) proposed by Buffington (1981) was used, and it was calculated the radiant thermal load index (RTL) proposed by Esmay (1979):

$$
\mathrm{BGHI}=\mathrm{Bt}+0,36 \mathrm{Tdp}+41,5
$$

where: $\mathrm{Bt}=$ black globe temperature $\left({ }^{\circ} \mathrm{C}\right)$; $\mathrm{Tdp}=$ dew-point temperature $\left({ }^{\circ} \mathrm{C}\right)$.

$$
\mathrm{RTL}=\sigma \mathrm{T}_{\mathrm{mr}}{ }^{4}, \mathrm{~W} / \mathrm{m}^{2} .
$$

where: $\sigma=$ constant of Stefan-Boltzmann $\left(5,67 \times 10^{-8} \mathrm{~W} \cdot \mathrm{m}^{-2}\right.$ $\left.\mathrm{K}^{-4}\right) ; \mathrm{T}_{\mathrm{mr}}=$ mean radiant temperature $\left({ }^{\circ} \mathrm{K}\right)$, where $\mathrm{T}_{\mathrm{mr}}=100$ $\left.\left\{2,51 \mathrm{Ws}^{0,5}(\mathrm{Bt}-\mathrm{Ta})+((\mathrm{Bt}+273) / 100)\right)^{4}\right\}^{0,25}$, where: $\mathrm{Ta}=$ air temperature $\left({ }^{\circ} \mathrm{C}\right) ; \mathrm{Bt}=$ black globe temperature $\left({ }^{\circ} \mathrm{C}\right)$; Ws $=$ wind speed $(\mathrm{m} / \mathrm{s})$.

To evaluate the availability of forage (Table 1), it was made an assessment before the entry of the animals by using the double sampling methodology proposed by Wilm et al. (1944) and Bremm et al. (2008) and the bromatological analyses (dry matter, crude protein and neutral detergent fiber) were performed according to the methodology described by Silva (1999).

The dry leaf supply was $28.33,13.97$ and $45.96 \%$ per day regarded to the body weight $(260 \mathrm{~kg}$ ) in the without shade, $8 \mathrm{~m}$ tree, and $18 \mathrm{~m}$ tree systems, respectively.

The experimental design was a completely randomized design with three systems and ten replications, with the following statistical model $\mathrm{Y}_{\mathrm{ijk}}=\mu+\mathrm{P}_{\mathrm{i}}+\mathrm{S}_{\mathrm{j}}+\mathrm{PS}_{\mathrm{ij}}+\mathrm{e}_{\mathrm{ijk}}$ where: $\mathrm{Y}_{\mathrm{ijk}}=$ observation $\mathrm{n}$-th measure of behavior made in the $\mathrm{i}$ period ,in $\mathrm{j}$ environment , in $\mathrm{k}$ animals ; $\mathrm{m}=$ overall average of all observations; $\mathrm{Pi}=\mathrm{i}$ period observation, $\mathrm{i}=1$, 2; $\mathrm{Sj}=$ observation in the $\mathrm{j}$ system, $\mathrm{j}=1,2,3$; PSij = effect of interaction of the $\mathrm{i}$ period observation and $\mathrm{j}$ system; eijk = random error associated with each observation.

The data of time and grazing, ruminating and resting frequency were subjected to analysis of variance and means compared by Tukey test at $5 \%$ probability using the program SISVAR (Ferreira, 2000).

\section{Results and Discussion}

The black globe-humidity index (BGHI) mean temperatures found in this experiment (Table 2) were higher than those reported by Azevedo et al. (2005), who considered the respiratory frequency and obtained upper critical values of 79, 77 and 76 for milk crossbred Holstein-Zebu (1/2, 3/4 and 7/8), respectively. However, in this work, Nellore heifers were used. The mean air temperature observed (Table 2) in the afternoon in the without shade, 8 - $\mathrm{m}$ trees and $18-\mathrm{m}$ tree systems were respectively, $35.9,34.9$ and $33.6^{\circ} \mathrm{C}$, which are above the upper critical temperature outside the thermoneutral zone for European origin cattle $\left(25\right.$ to $\left.27^{\circ} \mathrm{C}\right)$ for all systems and over the limit for the indians $\left(\mathrm{TCS}>35^{\circ} \mathrm{C}\right.$ ) (Silva, 2000) in the without shade system, which proved to restrain the welfare of animals.

The values observed in the temperature of globe-humidity index and radiant thermal load including the black globe temperature in with shade systems had mean values and

\begin{tabular}{|c|c|c|c|c|}
\hline & & No shade & $8 \mathrm{~m}$ trees & $18 \mathrm{~m}$ trees \\
\hline \multirow{3}{*}{ Leaf } & Dry matter (kg/ha) & 2,210 & 1,090 & 3,585 \\
\hline & Crude protein (\%) & 6.74 & 8.55 & 7.05 \\
\hline & Neutral detergent fiber (\%) & 70.84 & 64.93 & 70.74 \\
\hline \multirow{3}{*}{ Stem } & Dry matter (kg/ha) & 1,512 & 3,160 & 3,708 \\
\hline & Crude protein (\%) & 3.40 & 3.31 & 1.99 \\
\hline & Neutral detergent fiber (\%) & 74.21 & 77.40 & 78.36 \\
\hline Relation leaf:stem & & 1.46: 1 & $0.34: 1$ & 0.97: 1 \\
\hline Dead material & Dry matter (kg/ha) & 1,628 & 1,853 & 618 \\
\hline Inflorescence & Dry matter (kg/ha) & 0 & 436 & 0 \\
\hline
\end{tabular}

Table 1 - Composition of pasture in the systems 
Table 2 - Mean, minimum (Min) and maximum (Max) of environmental variables and indices of comfort heat in different systems

\begin{tabular}{|c|c|c|c|c|c|c|c|c|c|c|}
\hline \multirow[b]{3}{*}{ Variable } & \multirow[b]{3}{*}{ Period } & \multicolumn{9}{|c|}{ Silvopastoral system } \\
\hline & & \multicolumn{3}{|c|}{ No shade } & \multicolumn{3}{|c|}{$8 \mathrm{~m}$ - trees } & \multicolumn{3}{|c|}{$18 \mathrm{~m}$ - trees } \\
\hline & & Mean & Min & Max & Mean & Min & Max & Mean & Min & Max \\
\hline \multirow[t]{2}{*}{ Black globe temperature $\left({ }^{\circ} \mathrm{C}\right)$} & Morning & 36.1 & 27.0 & 40.0 & 32.4 & 21.0 & 42.0 & 30.8 & 20.0 & 44.0 \\
\hline & Afternoon & 42.5 & 37.0 & 48.0 & 39.6 & 32.0 & 51.0 & 39.7 & 31.0 & 52.0 \\
\hline \multirow[t]{2}{*}{ Air temperature $\left({ }^{\circ} \mathrm{C}\right)$} & Morning & 30.9 & 25.5 & 35.1 & 29.4 & 25.5 & 33.7 & 28.9 & 21.0 & 34.0 \\
\hline & Afternoon & 35.9 & 33.2 & 37.7 & 34.9 & 32.6 & 37.0 & 33.6 & 29.8 & 36.0 \\
\hline \multirow[t]{2}{*}{ Relative humidity (\%) } & Morning & 55.3 & 42.2 & 71.3 & 58.8 & 45.1 & 72.3 & 69.8 & 54.0 & 88.0 \\
\hline & Afternoon & 39.9 & 30.6 & 48.3 & 41.8 & 33.8 & 50.4 & 51.2 & 41.0 & 65.0 \\
\hline \multirow[t]{2}{*}{ Wind speed (m/s) } & Morning & 2.0 & 0.0 & 7.6 & 1.5 & 0.0 & 5.0 & 0.6 & 0.0 & 1.4 \\
\hline & Afternoon & 1.7 & 0.0 & 6.0 & 1.3 & 0.0 & 4.2 & 0.8 & 0.0 & 2.5 \\
\hline \multirow[t]{2}{*}{ Black globe-humidity index } & Morning & 86 & 77 & 91 & 82 & 70 & 92 & 82 & 69 & 96 \\
\hline & Afternoon & 92 & 87 & 97 & 89 & 81 & 102 & 90 & 81 & 102 \\
\hline \multirow{2}{*}{$\begin{array}{l}\text { Radiant thermal load } \\
\text { index }\left(\mathrm{W} / \mathrm{m}^{2}\right)\end{array}$} & Morning & 618 & 470 & 769 & 554 & 424 & 702 & 506 & 359 & 692 \\
\hline & Afternoon & 674 & 531 & 781 & 600 & 444 & 838 & 608 & 485 & 818 \\
\hline
\end{tabular}

lower minimums that were obtained in the without shade system in the morning and in the afternoon, demonstrating better environmental condition for the animals.

Cattle usually divide their days in alternating periods of grazing (ingestion), rumination and rest (idle), allocating ,on average, one third of the day or eight hours for each activity. The grazing time is usually eight hours and can reach up to 16 hours in extreme situations. This characteristic pattern of activity in cattle can be altered by routine activities such as milking, change of pickets, state of rotational grazing and, exceptionally, extreme weather, although it is quite stable in most situations and all animals in the group or flock seek to follow the same pattern (Hodgson, 1990).

The grazing time for the animals from shading systems, whose environmental conditions were better (Table 2), because of shade availability, showed two peaks, and sustained (Figure 1), one in the morning, between 11 a.m. and 12 p.m., and another starting between 1 p.m. and 2 p.m., with more time close to 4 p.m., an hour earlier than the without shade system. This result is in agreement with those obtained by Zanine et al. (2006), which, in an experiment with calves, heifers and cows grazing Brachiaria decumbens in without shade system, also found a similar distribution to that for a shading system for the daily time variation of grazing animals, which was more intense in the morning, reducing from 1 p.m. with a peak starting at 4 p.m, as reported by Van Soest (1994), who states that ruminants have default behavior of grazing during the day, eating quickly the food and chewing it later, and cattle usually grazed more intensely in the early morning and late afternoon, but this pattern can be changed by the amount of time of day and time of year.

Between 7 a.m. to 10 a.m. animals from without shade and 8 - $\mathrm{m}$ tree systems kept ruminating activities (Figure 1)
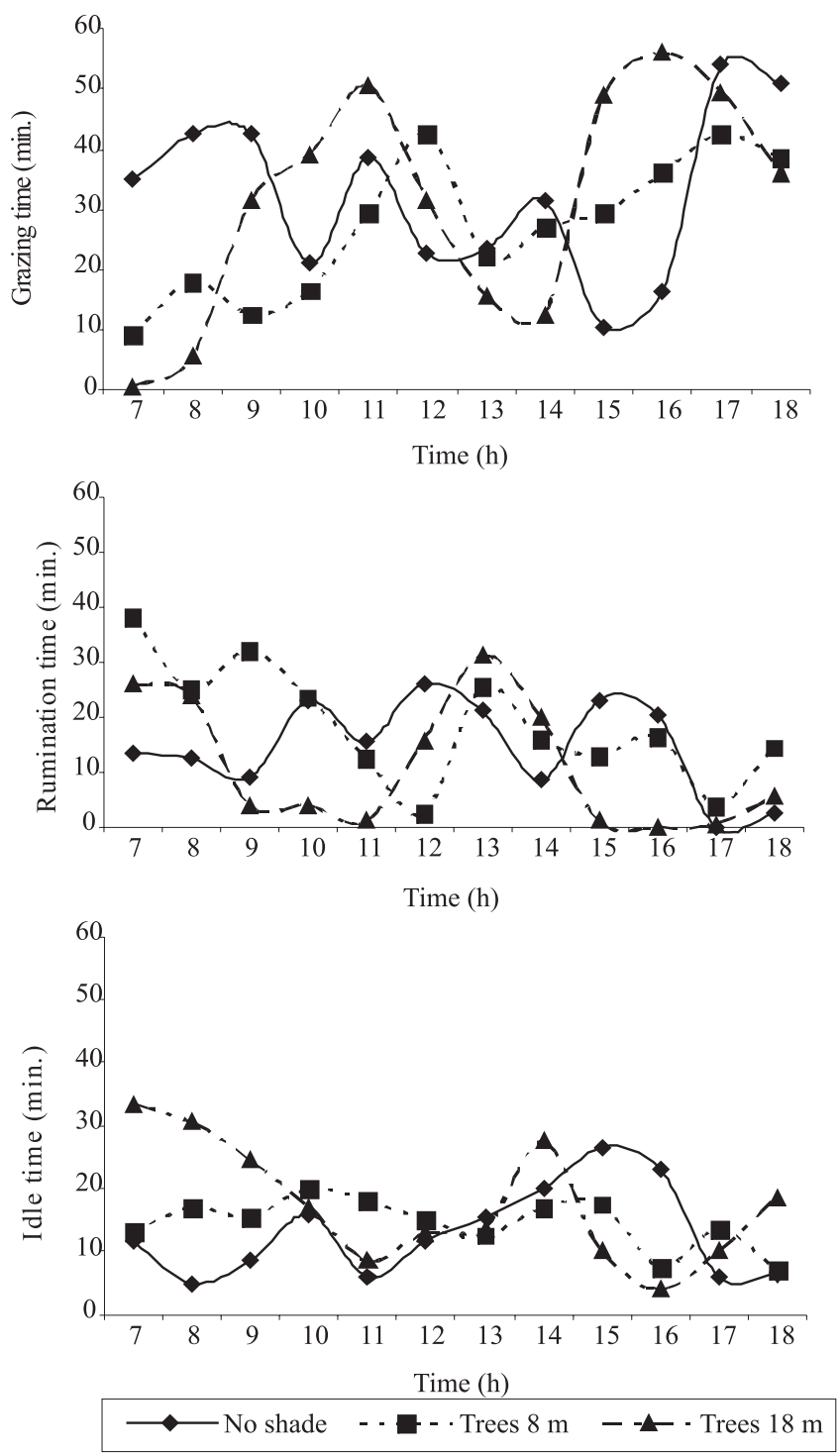

Figure 1 - Variation in time of ingestive behavior, at various times in silvopastoral systems with without shade, trees of $8 \mathrm{~m}$ and $18 \mathrm{~m}$. 
on the same level compared to the animals from $18 \mathrm{~m}$-tree system, which decreased rapidly, probably because they require more time to ruminate the structure of the forage consumed (Table 1). Animals from the without shade system showed three peaks of rumination (at 10 a.m., 12 p.m. and 3 p.m.), while those from $8 \mathrm{~m}$ tree systems showed two peaks, one from 7 a.m. to 9 a.m., slowly declining until 12 p.m., and another peak at 1 p.m., declining until 5 p.m.

In the $18 \mathrm{~m}$ tree system, the animals showed two rumination peaks, at 7 a.m. and 1 p.m. In both systems with trees, the animals behaved more uniformly, provided by improved environmental conditions. The permanency of animals in idle (Figure 1) in the system without a shade compared to the systems with trees, caused a peak of idle at 10 a.m., but, in general, that was lower than in shading systems.

Close to 3 p.m., the globe-humidity highest rate temperature time, all systems showed peaks, indicating that the animals were trying to reduce metabolic heat production because of the decreased grazing and ruminating time.

Distributions of behaviors during the day are in agreement with Hodgson (1990), who, grazing animals, observed 3 to 5 peaks of grazing throughout the day and the highest peaks occurred in the early morning and late afternoon.

The environmental conditions in the afternoon were more aggressive to the animals (Table 2) than in the morning, through a process of reradiation. This is because the thermal energy from the sun, which is absorbed by the environment, heat it, therefore resulting in the issuance by the environment long-wave infrared radiation, causing an increase in air temperature (Silva, 2000).

As analyzing the time of grazing animals (Table 3 ) with and without access to shade in the morning and afternoon, it was found a systems $\times$ time interaction $(\mathrm{P}<0.05)$ and in the system without shade, there were no differences $(\mathrm{P}>0.05)$ between the morning (202 minutes) and afternoon (187 minutes). However, the grazing frequency was higher
$(\mathrm{P}<0.05)$ in the morning (3.9) compared to the afternoon (3.17), following the largest numerical value of grazing time. Moreover, among animals of systems with access to shade, the grazing time in the afternoon (195.5 and 219 minutes for $8 \mathrm{~m}$ to $18 \mathrm{~m}$ tree systems) was higher $(\mathrm{P}<0.05)$ than in the morning (128 and 158.5 minutes, respectively), regardless to the tree height, since the animals were in better environmental conditions in wooded environment, because the presence of trees reduces the impact of the weather elements on the animals (Silva, 2000). Similarly, the grazing frequency in the $8 \mathrm{~m}$ tree system was higher $(\mathrm{P}<0.05)$ in the afternoon (4.47), following the values of grazing time. However, the grazing frequency in the $18 \mathrm{~m}$ tree system was similar $(\mathrm{P}>0.05)$ between the two periods (morning $=2.83$ and afternoon $=2.97$ ), which may indicate that the animals spent more time for meals in the afternoon.

The higher grazing time of the animals from the system without shade in the morning compared to other systems with shade may have been influenced by the memory of animals in relation to adverse environmental conditions that they would meet in the afternoon. Because of this, they sought to graze for longer time when environmental conditions were more favorable. According to Paranhos da Costa (2000), the animals have a manner of learning: The conditioning (or associative learning) through which connections between certain situations (involving places, people, etc.) and sensations are established. If the feelings are negative, they try to avoid situations associated with these sensations. This behavior was confirmed by Hotzel et al. (2005), who found that cows can discriminate between aversive and neutral handlers and that the condition of aversion remains for 180 days, even when there is reinforcement for more than five months. This hypothesis can be justified for long grazing in the afternoon by animals with access to shade because they knew the favorable environment they would meet in the afternoon.

Animals in the system without shade in the afternoon being exposed to the worst environmental conditions have

Table 3 - Time and frequency of grazing in silvopastoral systems in different periods of observation

\begin{tabular}{|c|c|c|c|c|c|c|}
\hline \multirow[b]{2}{*}{ Variable } & \multicolumn{6}{|c|}{ Silvopastoral system } \\
\hline & Period day & No shade & $8 \mathrm{~m}$ trees & $18 \mathrm{~m}$ trees & Mean & $\mathrm{CV}$ \\
\hline \multirow[t]{3}{*}{ Grazing time (minutes) } & Morning & $202.00 \mathrm{aA}$ & $128.00 \mathrm{cB}$ & $158.50 \mathrm{bB}$ & 162.83 & 19.29 \\
\hline & Afternoon & $187.00 \mathrm{bA}$ & $195.50 \mathrm{bA}$ & $219.00 \mathrm{aA}$ & 200.50 & \\
\hline & Mean & 194.50 & 161.75 & 188.75 & & \\
\hline \multirow[t]{3}{*}{ Frequency grazing } & Morning & $3.90 \mathrm{aA}$ & $3.70 \mathrm{aB}$ & $2.83 \mathrm{bA}$ & 3.48 & 31.02 \\
\hline & Afternoon & $3.17 \mathrm{bB}$ & $4.47 \mathrm{aA}$ & $2.97 \mathrm{bA}$ & 3.53 & \\
\hline & Mean & 3.53 & 4.08 & 2.90 & & \\
\hline Grazing in the shade (\%) & & 0 & 36.32 & 26.62 & & - \\
\hline
\end{tabular}

Means followed by lowercase different letters in lines and columns differ $(\mathrm{P}<0.05)$ by Tukey test. $\mathrm{CV}=$ coefficient of variation $(\%)$. 
sought to improve the balance of homeostasis not by increasing the grazing time and easing a thermal load of heat, so their grazing time was not compatible to animals in systems with shade. This result confirms reports by Marques et al. (2005), who observed that, at elevated temperature above the comfort zone, there is a reduction in food consumption, especially for those with high fiber content, where the animals sought to adjust their physiology and behavior to show appropriate responses to different characteristics and conditions of the adverse environment in which it is being created. Van Soest (1994) asserts that the best intake pattern suited for ruminants considers that environmental factors affect food ingestion (for example, heat stress reduces the intake, and the cold can increase it) and integrates them in the system that also considers the physiological state of the animal (in milking, growing or under environmental stresses) and quality of food.

The frequencies in grazing differed between systems by differences in the structure of grassland (Table 1) and environment (Table 2). Animals with access to shade grazed for more time in the sun. Therefore, in the $8 \mathrm{~m}$ tree system, the frequency was 36.32 , while in the $18 \mathrm{~m}$ tree system it was $26.62 \%$.

The total grazing time (363.33 minutes) was almost similar to that observed by Souza et al. (2007), who evaluated heifers grazing Brachiaria decumbens $(4,066 \mathrm{~kg} / \mathrm{ha} \mathrm{DM}$ green) from 7 a.m. to 5 p.m. and found 324.60 minutes. However, it was higher than that observed by Marques et al. (2003) who assessed ingestive behavior of steers for 24 hours in Panicum maximum cv IPR86 Millennium in the northwestern Paraná during the summer and found approximately $66.75 \%$ of grazing time from 6 a.m. to 6 p.m., with 310.52 minutes grazing time. Mendes Neto et al. (2007) also found that the food intake was higher during the day (75.68\% of feeding activity occurred between 6 a.m. and 6 p.m.).

According to Hodgson (1990), the time spent with ruminating ranges from 6 to 8 hours per day. However, Van Soest (1994) states that the rumination activity in cattle takes a maximum time varying from 10 to 11 hours a day, but it is influenced by the type of the diet, increasing rumination time for low quality pastures (high content of cell wall).

In the evaluation of ruminating time of the animals with and without access to shade in the morning and afternoon, a systems $\times$ time $(\mathrm{P}<0.05)$ interaction was found. In all systems, the rumination time was higher $(\mathrm{P}<0.05)$ in the morning. That was followed by the frequency in average grazing systems, which was 3.19 in the morning and 2.71 $(\mathrm{P}<0.05)$ in the afternoon. This result is in agreement with the statement by Van Soest (1994) that rumination time is highly variable and it can start minutes after food ingestion in periods ranging from minutes to two hours. Thus, rumination would occur after a large meal in the morning, which begins at dawn and runs until 9 a.m. Similar values in this work were found by Marques et al. (2003), who observed 108.72 minutes and 69.58 minutes values for the systems in the morning and in the afternoon, respectively.

Among the animals with access to shade, those of the $18 \mathrm{~m}$ tree system spent more time ruminating in the shade (66.28\%), while those of the $8 \mathrm{~m}$ tree system ruminated for half (49.77\%) of their time in the shade and half in the sun.

The total ruminating average time of 176.67 minutes (morning $=102.50$ and afternoon $=74.17$ minutes) of the animals was higher than that found by Souza et al. (2007), who evaluated heifers grazing Brachiaria decumbens $(4,066 \mathrm{~kg}$ / ha DM green) from 7 a.m. to 5 p.m. and found 53.82 minutes, also higher than that found by Zanine et al. (2006) which was 136.80 minutes during the day for dairy heifers grazing Brachiaria decumbens, with availability of $3.05 \mathrm{t} \mathrm{DM} /$ ha and leaf:stem ratio of 0.35 , but similar to those found by Marques et al . (2003) which was 178.30 minutes, and consistent with those obtained by Pereira et al. (1998), who, working with animals of the Limousin breed kept at non-shaded, observed a decrease in rumination time at the hottest times of the day.

The frequency on animals ruminating (Table 4) differed between systems $(\mathrm{P}<0.05)$ and it was higher in the $8 \mathrm{~m}$ tree system (3.58), followed by the systems without shade (3.05) and $18 \mathrm{~m}$ tree system (2.22). Animals in the $8 \mathrm{~m}$ tree system showed higher frequency in rumination, because of the canopy structure (Table 1), which enabled a faster filling of the rumen with coarser matter, causing a reduction in the size in order to increase the rate of rumination passage. The particle size and concentration of cell wall have proportional effect on the stimulation of rumination, which is made by tactile ways or by the pressure of coarse matter, captured by sensors present in the rumen wall (Van Soest, 1994).

According to Paranhos da Costa et al. (1983), the behavior of idle is the period in which the animals are not eating, ruminating or ingesting water.

During analyses of the animal idle time (Table 5) of the animals with and without access to shade in the morning and afternoon, it was found that there was a systems $\times$ time interaction $(\mathrm{P}<0.05)$ in which animals from the system without shade showed a higher idle time in the afternoon $(\mathrm{P}<0.05)$. Moreover, in systems with access to shade, the idle time was always higher $(\mathrm{P}<0.05)$ in the morning regardless to the tree height. Similarly, there was systems $x$ time interaction $(\mathrm{P}<0.05)$ for frequency of idle, which 
Table 4 - Time and frequency of rumination in the different systems in accordance with the observation periods

\begin{tabular}{|c|c|c|c|c|c|c|}
\hline & \multicolumn{6}{|c|}{ Silvopastoral system } \\
\hline & Period day & No shade & $8 \mathrm{~m}$ trees & $18 \mathrm{~m}$ trees & Mean & $\mathrm{CV}$ \\
\hline \multirow[t]{3}{*}{ Rumination time (minutes) } & Morning & $99.50 \mathrm{bA}$ & $133.50 \mathrm{aA}$ & 74.50c A & 102.50 & 31.71 \\
\hline & Afternoon & $75.50 \mathrm{aB}$ & $89.50 \mathrm{aB}$ & $57.50 \mathrm{bB}$ & 74.17 & \\
\hline & Mean & 87.50 & 111.50 & 66.00 & & \\
\hline \multirow[t]{3}{*}{ Frequency rumination } & Morning & 3.23 & 3.70 & 2.63 & $3.19 \mathrm{~A}$ & 30.23 \\
\hline & Afternoon & 2.87 & 3.47 & 1.80 & $2.71 \mathrm{~B}$ & \\
\hline & Mean & $3.05 b$ & $3.58 \mathrm{a}$ & $2.22 \mathrm{c}$ & & \\
\hline Ruminating in the shade (\%) & & 0 & 49.77 & 66.28 & & - \\
\hline
\end{tabular}

Means followed by different letters in lower case letters in lines and columns differ $(\mathrm{P}<0.05)$ by Tukey test.

$\mathrm{CV}=$ coefficient of variation (\%).

followed $(\mathrm{P}<0.05)$ the values of idle time regardless to the system.

The values of average 180 minute total idle time (P1 and P2 = $94.67=85.33$ ) were lower than those found by Souza et al. (2007) that evaluated this activity in heifers grazing Brachiaria decumbens (4,066 kg / ha DM green) from 7 a.m. to 5 p.m. and found 221.58 minutes.

On shading systems, the residence time of the animals grazing, ruminating and idling (Figure 2) was higher during the next 14 hours and proportional to the black globehumidity index.

In these systems, there was shade in the whole area until around 8 a.m. and after 5 p.m. because of sun gradient, explaining the demand for shade peaks in the early morning and late afternoon. In the morning, the animals spent more time in activities of rumination and idle compared to the afternoon and it was chosen to perform them in the shade, even with a lower black globe-humidity index, gradually reducing their activities in the shade until 11 a.m. Regardless to the period, the animals alternated their position, sometimes in the shade of the rank, sometimes in the sun, trying to control homeostasis, in an attempt to reduce the thermal stress caused by the incidence of direct solar radiation, confirming the condition of animal welfare.

The animals in $8 \mathrm{~m}$ to $18 \mathrm{~m}$ tree system carried out, respectively, the activities of grazing, ruminating and idle under the shade of the rank in an average of $43.49 \%$ and $49.81 \%$ of the total time periods which is below the rate observed by Leme et al. (2005) in study with crossbred Zebu cows grazing in silvopastoral system in the summer (from 6 a.m. to 6 p.m.), which carried out $68.6 \%$ of its activities in the shade. Nevertheless, they were bred and category animals, which are most susceptible to environmental stress compared to those used in this research.

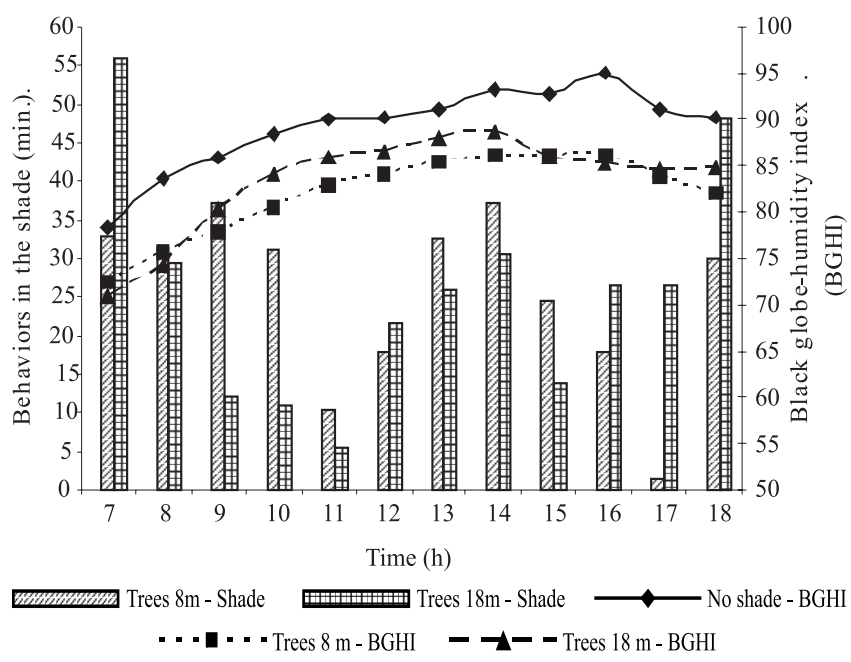

Figure 2 - Distribution of the behaviors in the shade and the black globe-humidity index at various times in silvopastoral systems.

Table 5 - Time and frequency in idle systems in accordance to the observation periods

\begin{tabular}{|c|c|c|c|c|c|c|}
\hline & \multicolumn{6}{|c|}{ Silvopastoral system } \\
\hline & Period day & No shade & $8 \mathrm{~m}$ trees & $18 \mathrm{~m}$ trees & Mean & $\mathrm{CV}$ \\
\hline \multirow[t]{3}{*}{ Idle time (minutes) } & Morning & $58.50 \mathrm{cB}$ & $98.50 \mathrm{bA}$ & $127.00 \mathrm{aA}$ & 94.67 & 40.28 \\
\hline & Afternoon & $97.50 \mathrm{aA}$ & $75.00 \mathrm{bB}$ & 83.50abB & 85.33 & \\
\hline & Mean & 78.00 & 86.75 & 105.25 & & \\
\hline \multirow[t]{3}{*}{ Frequency in idle } & Morning & $3.10 \mathrm{bB}$ & $4.47 \mathrm{aA}$ & $4.27 \mathrm{aA}$ & 3.94 & 35.50 \\
\hline & Afternoon & $3.80 \mathrm{aA}$ & $3.73 \mathrm{aB}$ & $3.07 \mathrm{aB}$ & 3.53 & \\
\hline & Mean & 3.45 & 4.10 & 3.67 & & \\
\hline Idle in the shade (\%) & & 0 & 44.38 & 56.53 & & - \\
\hline
\end{tabular}

Means followed by different letters in lower case letters in lines and columns differ $(\mathrm{P}<0.05)$ by Tukey test. $\mathrm{CV}=$ coefficient of variation (\%). 


\section{Conclusions}

Time of day influences the behavior and frequency of consumption and idle of heifers grazing in silvipastoral environments, but does not change the time and frequency of rumination. The ingestive behavior is influenced by the presence of trees in grazing environments.

\section{References}

AZEVEDO, M.; PIRES, M.F.A.; SATURNINO, H.M. et al. Estimativa de níveis críticos superiores do índice de temperatura e umidade para vacas leiteiras 1/2, 3/4 e 7/8 Holandês-Zebu em lactação. Revista Brasileira de Zootecnia, v.34, n.6, p.2000-2008, 2005.

BREMM, C.; ROCHA M.G.; FREITAS, F.K. et a1. Comportamento ingestivo de novilhas de corte submetidas a estratégias de suplementação em pastagens de aveia e azevém. Revista Brasileira de Zootecnia, v.37, n.7, p.1161-1167, 2008.

BUFFINGTON, D.E.; COLLAZO-AROCHO, A.; CANTON, G.H. et al. Black globe-humidity index (BGHI) as confort equation for dairy cows. Transactions of the American Society of Agricultural Engineers, v.24, p.711-714, 1981.

DETZEL, V.A. Arborização urbana: importância e avaliação econômica. In: CONGRESSO BRASILEIRO SOBRE ARBORIZAÇÃO URBANA, 1., 1992. Vitória. Anais... Vitória: 1992. p.39-52.

ESMAY, M.L. Principles of animal environment. West Port: Avi Publishing, 1979. 325p.

FERREIRA, D.F. Análises estatísticas por meio do Sisvar para Windows versão 4.0. In: REUNIÃO ANUAL DA REGIÃO BRASILEIRA DA SOCIEDADE INTERNACIONAL DE BIOMETRIA, 45., São Carlos. Anais... São Carlos: UFSCar, 2000. p.255-258.

HODGSON, J. Grazing management: science into practice. Longman Scientific \& Technical, 1990. 203p.

HÖTZEL, M.J.; MACHADO FILHO, L.C.P.; YUNES, M.C. et al. Influência de um Ordenhador Aversivo sobre a Produção Leiteira de Vacas da Raça Holandesa, Revista Brasileira de Zootecnia, v.34, n.4, p.1278-1284, 2005.

HUGHES, G.P.; REID, D. Studies on the behavior of cattle and sheep in relation to utilization of grass, Journal Agricultural Science, v.41, p.350-366, 1951.

INSTITUTO AGRONÔMICO DO ESTADO DO PARANÁ - IAPAR. Cartas climáticas do Estado do Paraná. Londrina: IAPAR, 1994. 49p. (Documento, 18).

LEME, T.M.S.P.; PIRES, M.F.A.; VERNEQUE, R.S. et al. Comportamento de vacas mestiças holandês $\mathrm{x}$ zebu, em pastagem de Brachiaria decumbens em sistema silvipastoril, Ciência Agrotécnica, v.29, n.3, p.668-675, 2005.

MARQUES, J.A.; CALDAS, S.F.; GROFF, A.M. et al. Comportamento de bovinos mestiços em confinamento com e sem acesso a sombra durante o período de verão. Campo Digital, v.1, n.1, p.54-59, 2006.

MARQUES, J.A.; LUGÃO, S.M.B.; ABRAHÃO, J.J.S. et al. Comportamento ingestivo de bovinos em pastagens de Panicum maximum cv IPR86 Milenio, sob diferentes doses de adubação. In: REUNIÃO ANUAL DA SOCIEDADE BRASILEIRA DE
ZOOTECNIA, 40., 2003, Santa Maria. Anais... Santa Maria: Sociedade Brasileira de Zootecnia, 2003. (CD-ROM).

MARQUES, J.A.; MAGGIONI, D.; ABRAHÃO, J.J.S. et al Comportamento de touros jovens em confinamento alojados isoladamente ou em grupo. Archivos Latinoamericanos Producción Animal, v.13, n.3, p.97-102, 2005.

MARTIN, P.; BATESON, P. Measuring behaviour: an introductory guide. 2.ed. Cambridge: Cambridge University Press, 1993. 222p. MENDES NETO, J.; CAMPOS J.M.S.; VALADARES, S.C. et al. Comportamento ingestivo de novilhas leiteiras alimentadas com polpa cítrica em substituição ao feno de capim-tifton 85 , Revista Brasileira de Zootecnia, v.36, n.3, p.618-625, 2007.

PARANHOS DA COSTA, M.J.R. Ambiência na produção de bovinos de corte a pasto. In: ENCONTRO ANUAL DE ETOLOGIA, 18., 2000, Florianopolis. Anais... Florianopolis, 2000. p.26-42.

PARANHOS DA COSTA, M.J.R. Comportamento dos animais de fazenda: reflexos na produtividade. In: ENCONTRO ANUAL DE ETOLOGIA, 5., 1987, Florianópolis. Anais... Jaboticabal: FUNEP, 1987. p.159-168.

PARANHOS DA COSTA, M.J.R.; MESQUITA, J.C.; JUNQUEIRA, FILHO, A.A. Comportamento de vacas Holandesas em pastagem. In: ENCONTRO PAULISTA DE ETOLOGIA, 1983, Jaboticabal. Anais... Jaboticabal: UNESP/FCAVJ, 1983. p.251.

PEREIRA, A.M.F.; ALVES, A.; MIRA, M. et al. Influencia da existência de sombra no comportamento e desempenho produtivo de bezerros da raça Limousin em confinamento. In: CONGRESSO BRASILEIRO DE BIOMETEOROLOGIA, 2. 1998, Goiânia. Anais... Goiânia: Universidade Católica de Goiás, 1998. p.354-360.

SILVA, F.C. Manual de análises químicas de solos, plantas e fertilizantes. 1.ed. Rio de Janeiro CNPS, 1999. 370p.

SILVA, K.O.; SILVA, I.J.O.; SOARES, A.M. et al. Caracterização da qualidade da sombra de árvores, através de índices de conforto térmico para a região de Lavras-MG. In: CONGRESSO BRASILEIRO DE ENGENHARIA AGRÍCOLA, 24., 1995, Viçosa, MG. Anais...Viçosa, MG: Universidade Federal de Viçosa, 1995. v.1. p.131-131.

SILVA, R.G. Introdução à bioclimatologia animal. São Paulo: Nobel, 2000. 286p.

SILVA, R.R.; SILVA F.F.; PRADO, I.N. et al., Comportamento ingestivo de bovinos. Aspectos metodológicos, Archivos de Zootecnia, v.55, n.211, p.293-296, 2006.

SOUZA, S.R.M.B.O.; ITAVO, L.C.V.; RIMOLI, J. et. al. Comportamento ingestivo diurno de bovinos em confinamento e em pastagens. Archivos de Zootecnia, v.56, n.213, p.67-70, 2007.

SWENSON, M.J. Fisiologia dos animais domésticos. Rio de Janeiro: Guanabara Koogan, 1988. 799p.

THUROW, J.M.; NABINGER, C.; CASTILHOS, Z.M.S. et al. Estrutura da vegetação e comportamento ingestivo de novilhos em pastagem natural do Rio Grande do Sul. Revista Brasileira de Zootecnia, v.38, n.5, p.818-826, 2009.

VAN SOEST, P.J. Nutritional ecology of the ruminant. Cornel: Ithaca, 1994. 476p.

WILM, H.G.; COSTELLO, O.F.; KLIPPLE, G.E. Estimating forage yield by the double sampling method, Journal American Society Agronomic, v.36, n.1, p.194-203, 1944.

ZANINE, A.M.; SANTOS, E.M.; PARENTE, H.N. et al. Comportamento da ingestão em bovinos (ruminantes) em pastagem de capim Brachiaria decumbens na região CentroOeste do Brasil. Archives of Veterinary Science, v.11, n.2, p.17-24, 2006. 